\title{
Polymorphism in the internal transcribed spacer (ITS) of the ribosomal DNA of 26 isolates of ectomycorrhizal fungi
}

\author{
Eliane A. Gomes ${ }^{1}$, Maria Catarina M. Kasuya ${ }^{2}$, Everaldo G. de Barros ${ }^{3}$, Arnaldo C. Borges ${ }^{2}$ \\ and Elza F. Araújo ${ }^{2}$ \\ ${ }^{1}$ Núcleo de Biologia Aplicada - Embrapa Milho e Sorgo, Sete Lagoas, MG, Brazil. \\ ${ }^{2}$ Departamento de Microbiologia / BIOAGRO, Universidade Federal de Viçosa, Viçosa, MG, Brazil. \\ ${ }^{3}$ Departamento de Biologia Geral / BIOAGRO, Universidade Federal de Viçosa, Viçosa, MG, Brazil.
}

\begin{abstract}
Inter- and intraspecific variation among 26 isolates of ectomycorrhizal fungi belonging to 8 genera and 19 species were evaluated by analysis of the internal transcribed sequence (ITS) of the rDNA region using restriction fragment length polymorphism (RFLP). The ITS region was first amplified by polymerase chain reaction (PCR) with specific primers and then cleaved with different restriction enzymes. Amplification products, which ranged between 560 and 750 base pairs (bp), were obtained for all the isolates analyzed. The degree of polymorphism observed did not allow proper identification of most of the isolates. Cleavage of amplified fragments with the restriction enzymes Alu I, Hae III, Hinf I, and Hpa II revealed extensive polymorphism. All eight genera and most species presented specific restriction patterns. Species not identifiable by a specific pattern belonged to two genera: Rhizopogon ( $R$. nigrescens, $R$. reaii, $R$. roseolus, $R$. rubescens and Rhizopogon sp.), and Laccaria (L. bicolor and L. amethystea). Our data confirm the potential of ITS region PCR-RFLP for the molecular characterization of ectomycorrhizal fungi and their identification and monitoring in artificial inoculation programs.
\end{abstract}

Key words: DNA fingerprinting, ectomycorrhizal fungi, internal transcribed spacer (ITS), PCR-RFLP, ribosomal DNA (rDNA).

Received: April 6, 1999; accepted: September 3, 2002.

\section{Introduction}

Ectomycorrhizal fungi have an important role in forest ecosystems because they mutualistically associate with different plant species, thereby increasing nutrient absorption while protecting the host plant against pathogens and abiotic stresses (Smith and Read, 1997; Allen, 1991). Taxonomically diverse, these fungi include between 5,000 and 6,000 species, mainly basidiomycetes (Molina et al., 1992).

Phenotypic differences between two isolates of the same species of an ectomycorrhizal fungus may be as pronounced as the differences between two distinct species, and for this reason identification of these fungi is not clear-cut (De la Bastide et al., 1995). Identification of ectomycorrhizal fungi is mainly based on the analysis of sporocarps whose presence is triggered by specific environmental conditions (Egger, 1995; Gardes and Bruns, 1996). Usually the identification of the mycosymbiont by morphological analyses of the mycorrhiza is more feasible than sporocarp analyses, al-

Send correspondence to Elza Fernandes de Araújo. Departamento de Microbiologia / BIOAGRO, Universidade Federal de Viçosa, 36571-000 Viçosa, MG, Brazil. E-mail: ezfa@mail.ufv.br. though special skills are required to directly analyze a root-attached symbiont (Karén et al., 1997).

DNA-based molecular techniques combining the polymerase chain reaction (PCR) with analysis of restriction fragment length polymorphisms (RFLP) represent new tools to aid in properly identifying ectomycorrhizal fungi. The PCR-RFLP technique, coupling two known procedures to detect polymorphisms in DNA regions which have been amplified by specific oligonucleotide primers and restricted with different endonucleases, has been successfully used to analyze regions of ribosomal DNA of ectomycorrhizal fungi (Gardes et al., 1991; Erland et al., 1994; Henrion et al., 1994; Farmer and Sylvia, 1998; Gomes et al., 1999; Glen et al., 2001a). The internal transcribed spacer (ITS) region separating genes $17 \mathrm{~S}$ and $25 \mathrm{~S}$, can be amplified by specific primers anchored in these two units. Since the ITS region is highly conserved intraspecifically but variable between different species it is often used in taxonomy (Bruns et al., 1991; Hillis and Dixon, 1991), but ITS region polymorphism for identifying ectomycorrhizal fungi species has been determined for only a restricted number of species, leaving its full potential as a taxonomic tool as yet unexplored (Karén et al., 1997). 
In the work published in this paper, 26 isolates of ectomycorrhizal fungi belonging to 8 genera and 19 different species were analyzed using the PCR-RFLP technique as applied to the ITS regions of these fungi. These analyses aimed to confirm the classification of these fungi and also to find markers able to facilitate the identification of specific isolates for breeding purposes.

\section{Materials and Methods}

\section{Fungal isolates and culture conditions}

Ectomycorrhizal fungi isolates (Table I) were obtained from the fungal collection maintained at the Laboratory of Mycorrhizal Associations, Department of Microbiology, Federal University of Viçosa, Minas Gerais, Brazil. Cultures were maintained in Petri dishes containing modified Melin-Norkrans agar medium (MMN) (Marx, 1969) for 25 days at $28{ }^{\circ} \mathrm{C}$. Mycelia for DNA extraction were obtained by inoculating MMN broth with agar plugs containing mycelia collected from actively growing colony margins, followed by 25 days static incubation at $28^{\circ} \mathrm{C}$. Ectomycorrhizae were obtained as described by Junghans et al. (1998).

\section{DNA extraction}

DNA was extracted from 0.5 to $1.0 \mathrm{~g}$ of fresh mycelium or ectomycorrhizae, according to the method of Schäfer and Wöstemeyer (1992) as modified by Junghans et al. (1998). DNA concentration was estimated by comparison with known standards in $1 \%(\mathrm{w} / \mathrm{v})$ agarose gels stained with ethidium bromide.

\section{PCR amplification and RFLP analysis}

The primer pairs used to amplify the rDNA ITS region (ITS1 and ITS4) have been described by White et al. (1990). The cycling parameters were: 40 cycles, each cycle

Table I - The ectomycorrhizal fungi studied and their origin and hosts.

\begin{tabular}{|c|c|c|c|c|}
\hline $\mathrm{N}^{\mathrm{o}}$ & Species & Isolate & Origin & Host \\
\hline 1 & Rhizopogon nigrescens & CK 4 & Viçosa - MG ${ }^{\mathrm{a}}$ - Brazil & Pinus sp. \\
\hline 2 & R. reaii & CK 7 & Viçosa - MG - Brazil & P. caribaea \\
\hline 3 & R. roseolus & CK 29 & Viçosa - MG - Brazil & P. patula \\
\hline 4 & R. roseolus & CK 30 & Viçosa - MG - Brazil & P. patula \\
\hline 5 & R. roseolus & CK 31 & Viçosa - MG - Brazil & P. patula \\
\hline 6 & R. roseolus & CK 32 & Viçosa - MG - Brazil & P. patula \\
\hline 7 & R. roseolus & CK 33 & Viçosa - MG - Brazil & P. patula \\
\hline 8 & R. vinicolor & A 153 & USA & Tsuga heterophylla \\
\hline 9 & R. rubescens & DR 181 & Unknown & P. resinosa \\
\hline 10 & Rhizopogon sp. & RN ITA & Itabira - MG - Brazil & P. elliottii \\
\hline 11 & R. subcaerulescens & RS1USA & Oregon - USA & Unknown \\
\hline 12 & Suillus granulatus & CK 13 & Viçosa - MG - Brazil & P. caribaea \\
\hline 13 & S. luteus & 9012 & Unknown & P. nigricans \\
\hline 14 & S. granulatus & SGEB & Viçosa - MG - Brazil & Pinus sp. \\
\hline 15 & S. granulatus & SG 91 & Viçosa - MG - Brazil & Pinus sp. \\
\hline 16 & S. brevipes & 7598 & Unknown & P. contorta \\
\hline 17 & Laccaria laccata & S 444 & Oregon - USA & Pseudotsuga sp. \\
\hline 18 & L. amethystea & DR 227 & USA & Unknown \\
\hline 19 & L. bicolor & DR 72 & USA & Unknown \\
\hline 20 & Scleroderma sp. & SCL ITA & Itabira - MG - Brazil & P. elliottii \\
\hline 21 & S. areolatum & DR 165 & USA & Quercus sp. \\
\hline 22 & Cenococcum geophilum & CGL & France & Eucalyptus sp. \\
\hline 23 & C. geophilum & CGP & USA & Pinus sp. \\
\hline 24 & Hebeloma cylindrosporum & $\mathrm{HC}$ & France & Unknown \\
\hline 25 & Paxillus involutus & PI & France & E. dalrympleana \\
\hline 26 & Pisolithus tinctorius & PT $145^{*}$ & Florianópolis - $\mathrm{SC}^{\mathrm{b}}$ - Brazil & Eucalyptus sp. \\
\hline 27 & P. tinctorius & PT 90A* & Viçosa - MG - Brazil & Eucalyptus sp. \\
\hline
\end{tabular}

${ }^{\mathrm{a}}$ The state of Minas Gerais.

${ }^{\mathrm{b}}$ The state of Santa Catarina.

*Used for inoculation of Eucalyptus grandis. 
consisting of a denaturation step at $94{ }^{\circ} \mathrm{C}$ for $1 \mathrm{~min}$, an annealing step at $50{ }^{\circ} \mathrm{C}$ for $1 \mathrm{~min}$ and an extension step at $72{ }^{\circ} \mathrm{C}$ for $1 \mathrm{~min} 30 \mathrm{~s}$. After the 40th cycle, a final extension step was performed at $72{ }^{\circ} \mathrm{C}$ for $7 \mathrm{~min}$. Components for $25 \mu \mathrm{L}$ PCR reactions were: $10 \mathrm{ng}$ of DNA template, 40 pmoles of each primer, $10 \mathrm{mM}$ Tris- $\mathrm{HCl}(\mathrm{pH} 8.3)$, $50 \mathrm{mM} \mathrm{KCl}, 2 \mathrm{mM} \mathrm{MgCl}$, $0.1 \mathrm{mM}$ of each dNTP (dGTP, $\mathrm{dCTP}, \mathrm{dATP}$ and dTTP) and 1 unit of Taq DNA polymerase (Invitrogen, Carlsbad, CA, USA). Negative controls (no DNA template) were included in every experiment. The amplification reaction was performed in a thermocycler PTC - 100 (MJ Research, Inc., Waltham, MA, USA). After amplification, DNA products were separated by electrophoresis in a $1.5 \%(\mathrm{w} / \mathrm{v})$ agarose gel immersed in TBE buffer (90 mM Tris-borate, 2 mM EDTA, pH 8.0) or precipitated for RFLP analysis. Precipitation was done by adding $100 \mathrm{mM} \mathrm{NaCl}$ and 2.5 volumes of absolute ethanol. Samples were kept at $-20{ }^{\circ} \mathrm{C}$ for $2 \mathrm{~h}$ and centrifuged at $12,000 \mathrm{x} g$ for $30 \mathrm{~min}$. The pellet was washed with $70 \%$ (v/v) ethanol, re-suspended in $10 \mu \mathrm{L}$ of water and digested with different restriction enzymes. The DNA fragments were size-fractionated in $2 \%(\mathrm{w} / \mathrm{v})$ agarose gel, stained with ethidium bromide $(0.5 \mu \mathrm{g} / \mathrm{mL})$ and photographed under UV light, either with a Polaroid camera or the images were captured and stored using the Eagle Eye II photodocumentation system (Stratagene, La Jolla, CA, USA).

\section{Data analysis}

After restriction with endonucleases the amplification products were scored as 1 (presence) or 0 (absence) of a restriction site and used for determining genetic distances between the isolates ( Nei and Li, 1979). These distances were used to cluster the isolates by the unweighted pair group method with averages (UPGMA) method using the Statistica program (version 4.5 for Windows, StatSoft, Inc. 1993, Tulsa, OK, USA).

\section{Results}

The internal transcribed spacer (ITS) of the rDNA region of 26 isolates belonging to 8 genera of ectomycorrhizal fungi showed extensive length polymorphism (Figure 1), PCR amplification with specific primers for the ITS region generated bands ranging from 560 to $750 \mathrm{bp}$. Figure 1 shows that all but two species (Suillus brevipes and Hebeloma cylindrosporum) presented only one amplification product. No difference was detected between the 11 Rhizopogon isolates analyzed, while the amplification patterns for all three Suillus species were quite distinct. No polymorphism was observed within the three Laccaria species nor between the two Cenococcum geophilum isolates, although polymorphism was observed between the two Scleroderma isolates.

To detect a wider range of polymorphisms, the PCR products were cleaved with the restriction enzymes Alu I, Hae III, Hinf I, and Hpa II (Table II). Figure 2 shows the restriction patterns obtained with Alu I. However, restriction patterns with all these enzymes could not distinguish between the nine Rhizopogon isolates and for this reason the PCR products from these isolates were further cleaved with three other enzymes ( $A v a$ II, Mbo I, and Taq I) but still no polymorphism was detected. Only two of these isolates, belonging to the species $R$. subcaerulescens (RS1USA) and $R$. vinicolor (A 153), showed different patterns compared to the others. $R$. subcaerulescens showed a distinct pattern with all three enzymes and $R$. vinicolor, with enzymes Alu I and Ava II. All other species, except L. bicolor and $L$. amethystea, could be identified by at least one restriction enzyme pattern.

Restriction fragments obtained with all the endonucleases tested were used to determine genetic distances between the genotypes and cluster them into specific groups (Figure 3). In general, isolates grouped according to their genus, e.g. Rhizopogon, Laccaria, and Cenococcum isolates were clustered into three distinct groups. However,

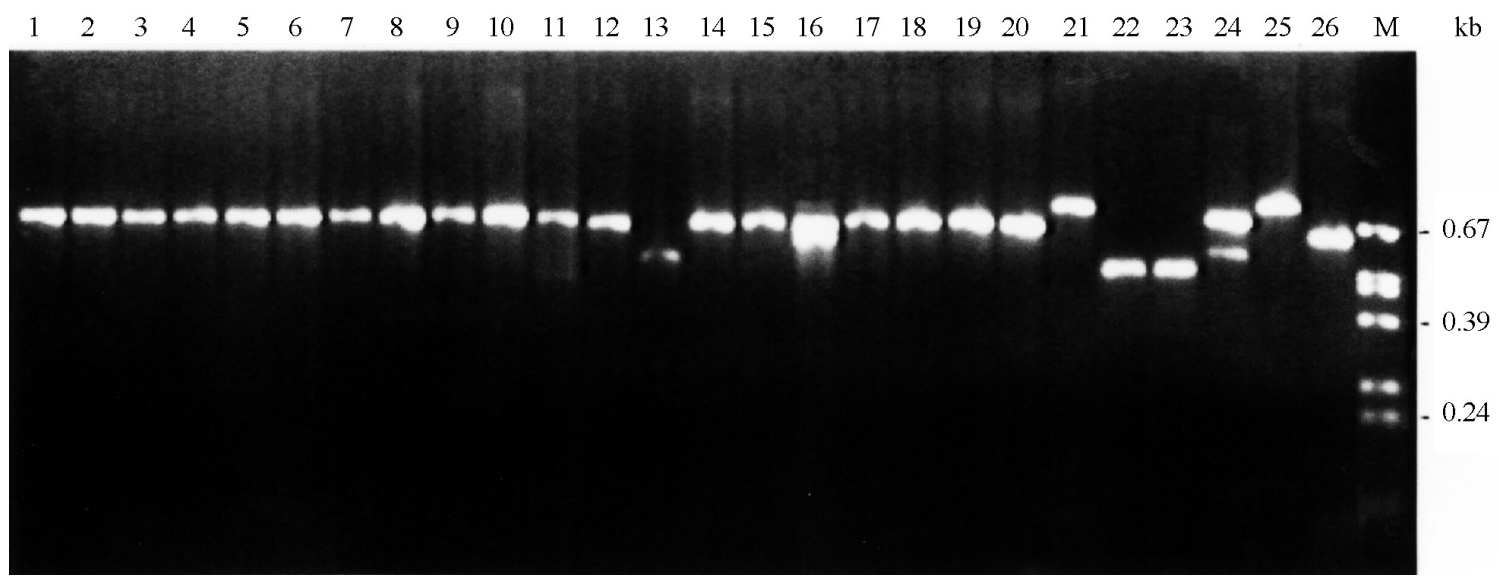

Figure 1 - Gel electrophoresis of the amplified rDNA internal transcribed sequence (ITS) region of 26 ectomycorrhizal fungal isolates. Lanes are numbered according to the isolate identification scheme given in Table I. Size markers (pUC 19 digested with Hinf I and Rsa I) are indicated by M. 
Table II - Restriction fragments (pair bases) of the internal transcribed spacer (ITS) rDNA amplified regions of ectomycorrhizal fungi isolates produced by different restriction enzymes.

\begin{tabular}{|c|c|c|c|c|c|c|c|c|c|c|c|c|c|c|c|c|c|c|c|}
\hline \multirow{3}{*}{$\frac{\text { Isolate }}{\text { CK } 4}$} & \multicolumn{5}{|c|}{ Alu $\mathrm{I}$} & \multicolumn{4}{|c|}{ Hae III } & \multicolumn{4}{|c|}{ Hpa II } & \multicolumn{6}{|c|}{$\operatorname{Hinf} \mathrm{I}$} \\
\hline & \multicolumn{5}{|c|}{ Fragment sizes (bp) } & \multicolumn{4}{|c|}{ Fragment sizes (bp) } & \multicolumn{4}{|c|}{ Fragment sizes (bp) } & \multicolumn{6}{|c|}{ Fragment sizes (bp) } \\
\hline & 400 & 290 & 60 & & & 730 & & & & 460 & 260 & & & 240 & 210 & 140 & 120 & & \\
\hline CK 7 & 400 & 290 & 60 & & & 730 & & & & 460 & 260 & & & 240 & 210 & 140 & 120 & & \\
\hline CK 29 & 400 & 290 & 60 & & & 730 & & & & 460 & 260 & & & 240 & 210 & 140 & 120 & & \\
\hline CK 30 & 400 & 290 & 60 & & & 730 & & & & 460 & 260 & & & 240 & 210 & 140 & 120 & & \\
\hline CK 31 & 400 & 290 & 60 & & & 730 & & & & 460 & 260 & & & 240 & 210 & 140 & 120 & & \\
\hline CK 32 & 400 & 290 & 60 & & & 730 & & & & 460 & 260 & & & 240 & 210 & 140 & 120 & & \\
\hline CK 33 & 400 & 290 & 60 & & & 730 & & & & 460 & 260 & & & 240 & 210 & 140 & 120 & & \\
\hline A 153 & 650 & 60 & & & & 730 & & & & 460 & 260 & & & 240 & 210 & 140 & 120 & & \\
\hline DR 181 & 400 & 290 & 60 & & & 730 & & & & 460 & 260 & & & 240 & 210 & 140 & 120 & & \\
\hline RN ITA & 400 & 290 & 60 & & & 730 & & & & 460 & 260 & & & 240 & 210 & 140 & 120 & & \\
\hline RS1USA & 430 & 300 & & & & 660 & & & & 340 & 170 & 140 & & 230 & 200 & 120 & 110 & & \\
\hline CK 13 & 610 & 80 & & & & 460 & 170 & 90 & & 330 & 170 & 140 & 90 & 190 & 130 & 70 & 30 & & \\
\hline 9012 & 400 & 140 & & & & 260 & 110 & 70 & & 260 & 210 & 190 & & 300 & 180 & 100 & & & \\
\hline SGEB & 610 & 80 & & & & 460 & 170 & 90 & & 330 & 170 & 140 & 90 & 190 & 130 & 70 & 30 & & \\
\hline SG 91 & 610 & 80 & & & & 460 & 170 & 90 & & 330 & 170 & 140 & 90 & 190 & 130 & 70 & 30 & & \\
\hline 7598 & 610 & 380 & 170 & 140 & & 540 & 430 & 140 & & 420 & 360 & 250 & 180 & 350 & 270 & 210 & 140 & & \\
\hline S 444 & 410 & 250 & 60 & & & 710 & & & & 720 & & & & 360 & 340 & & & & \\
\hline DR 227 & 410 & 130 & 120 & 60 & & 710 & & & & 720 & & & & 360 & 340 & & & & \\
\hline DR 72 & 410 & 130 & 120 & 60 & & 710 & & & & 720 & & & & 360 & 340 & & & & \\
\hline SCL ITA & 380 & 260 & & & & 330 & 200 & 90 & & 660 & & & & 250 & 200 & 120 & 40 & & \\
\hline DR 165 & 450 & 190 & 60 & & & 330 & 150 & 100 & 80 & 510 & 160 & 60 & & 350 & 260 & 130 & 50 & & \\
\hline CGL & 380 & 140 & & & & 430 & 90 & & & 400 & 100 & 70 & & 170 & 150 & 110 & 70 & 30 & \\
\hline CGP & 360 & 140 & & & & 440 & 90 & & & 400 & 100 & 70 & & 190 & 170 & 120 & 90 & 50 & \\
\hline $\mathrm{HC}$ & 510 & 320 & 260 & 200 & 170 & 630 & 450 & 310 & & 530 & 360 & 340 & 190 & 360 & 300 & 280 & 180 & 140 & 110 \\
\hline PI & 510 & 230 & & & & 530 & 130 & & & 300 & 240 & & & 380 & 350 & & & & \\
\hline PT 145 & 360 & 90 & 80 & & & 620 & & & & 350 & 240 & 60 & & 350 & 250 & 40 & & & \\
\hline
\end{tabular}

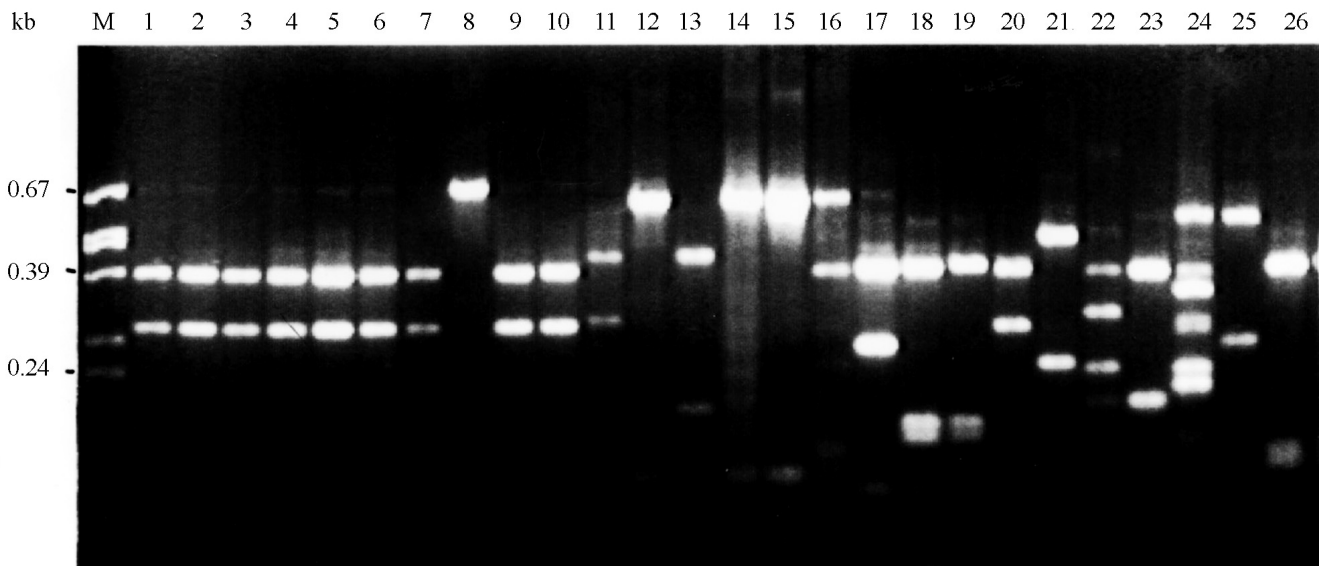

Figure 2 - Gel electrophoresis of the amplified rDNA internal transcribed sequence (ITS) region of 26 ectomycorrhizal fungal isolates digested with the Alu I restriction enzyme. Lanes are numbered according to the isolate identification scheme given in Table I. Size markers (pUC 19 digested with Hinf I and $R s a \mathrm{I})$ are indicated by $\mathrm{M}$. 


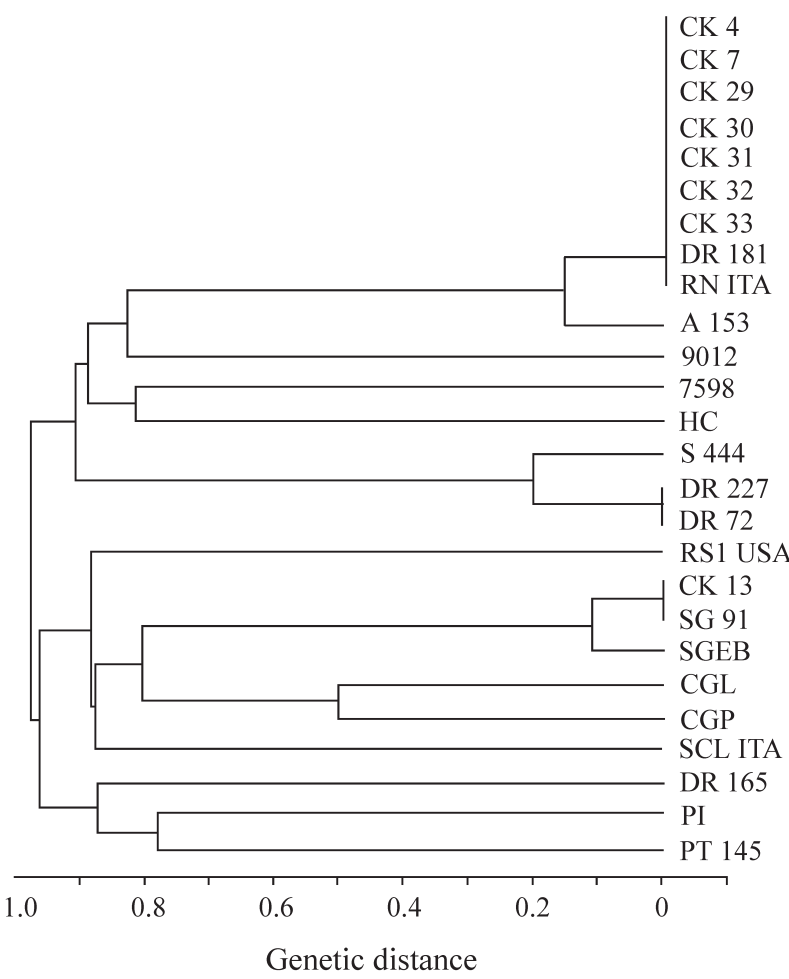

Figure 3 - Unweighted pair group method with averages (UPGMA) cluster diagram of the relationships between 26 ectomycorrhizal fungi isolates. The dendrogram was based on genetic similarity coefficients determined by the presence and absence of rDNA internal transcribed sequence (ITS) region restriction enzyme patterns.

as shown in Figure 3, one Rhizopogon (RS1USA) and two Suillus (7598 and 9012) isolates were clustered in groups distinct from those specific for their genera and each of the two Scleroderma isolates formed a separate group.

The rDNA ITS region of ectomycorrhizae amplified successfully with the ITS1/ITS4 primer pair, the electrophoretic pattern of the amplification products showing two bands (Figure 4).

\section{Discussion}

Detection of polymorphism using PCR-RFLP analyses of the rDNA ITS region has been successfully used for identifying several species of fungi (Amicucci et al., 1996). This simple technique requires only minute amounts of DNA and two specific primers flanking the ITS region. We found that the amplification products for the ITS region of 26 isolates of ectomycorrhizal fungi collected in Brazil, the United States and France ranged from 560 to 750 bp, coinciding with the sizes obtained for other ectomycorrhizal fungi (Gardes et al., 1991; Káren et al., 1997). Despite the length polymorphism observed for many of the isolates, ITS analysis alone was not able to separate all the genotypes, the exceptions being $S$. brevipes and $H$. cylindrosporum which presented two amplification products allowing their identification in relation to the other isolates (Figure 1). These two bands may be due to either

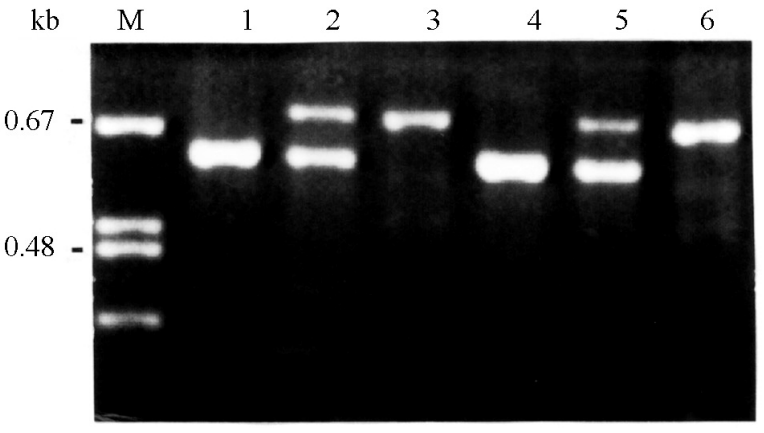

Figure 4 - Gel electrophoresis of the amplified rDNA internal transcribed sequence (ITS) region of the Eucalyptus grandis - Pisolithus tinctorius ectomycorrhizae. (1) P. tinctorius (PT 90A); (2) E. grandis - P. tinctorius (PT 90A) ectomycorrhizae; (3) E. grandis; (4) P. tinctorius (PT 145); (5) E. grandis $-P$. tinctorius (PT 145) ectomycorrhizae; (6) E. grandis. Size markers (pUC 19 digested with Hinf I and Rsa I) are indicated by M.

polymorphism within the rDNA repetitive unit or the presence in the same isolate of more than one nucleus bearing different rDNA sequences (Sanders et al., 1996).

A low degree of ITS region intraspecific polymorphism in ectomycorrhizal fungi has been reported by other authors (Gardes et al., 1991; Erland et al., 1994). According to Karén et al. (1997) ITS region intraspecific polymorphism varies among different genera and species, although no general conclusion can be drawn due to the small number of genera and species analyzed.

On the other hand, length polymorphism analysis of the ITS region followed by endonuclease restriction was sufficient to categorize most of the 26 isolates studied by us and place them in their correct species (Figure 2). RFLP analysis of the ITS region has been suggested by several authors as a means for discriminating between ectomycorrhizal fungi at species level (Gardes et al., 1991; Bruns et al., 1991). At genus level, ITS region fragment length polymorphism separated the 26 isolates into their 8 genera with any of the enzymes used.

Cleavage of the ITS region with Alu I (Figure 2) allowed differentiation of 12 out of the 19 species studied. However, none of the restriction enzymes produced a distinct pattern for five Rhizopogon species (R. nigrescens, $R$. reaii, $R$. roseolus, $R$. rubescens, and Rhizopogon sp.) and two Laccaria species (L. bicolor and L. amethystea).

Martin et al. (1998) analyzed the nuclear rDNA ITS region of Rhizopogon, in order to reexamine its present taxonomic classification in terms of the presence of specific DNA polymorphisms, and found that, based on both gel electrophoresis of digested PCR products and previous morphological observations, the five different species represent only one species, $R$. villosulus.

Cleavage of the ITS region of Pisolithus tinctorius isolate PT 145 resulted in the same DNA fragment pattern presented by other Pisolithus isolates collected in Brazil (Gomes et al., 1999). Indeed, cluster analysis based on RAPD-PCR analysis grouped the Brazilian isolates, while 
isolates collected in the USA and France have been shown to be quite distinct (Junghans et al., 1998).

The two bands observed by us on the PCR amplified ITS region of ectomycorrhizae correspond to plant and fungi patterns, this result confirming that ITS1/ITS4 primers are not fungi specific (Paolocci et al., 1995 and Amicucci et al., 1996). However, in some cases, heterologous DNA from the plant material did not interfere with PCR amplification (Gardes et al., 1991; Henrion et al., 1992; Erland, 1995). Glen et al. (2001b) tested six primers pairs (targeting three nuclear and three mitochondrial regions) for specificity, sensitivity and species discrimination on identified collections of fungi. Two sets of these primers, one newly designed and targeting the ITS region and the other amplifying a ribosomal DNA fragment of the large mitochondrial subunit met the requirements of high specificity and sensitivity, amplifying DNA from a broad range of the larger basidiomycetes, with no amplification of plant, bacterial or ascomycete DNA. These specific primers discriminated fungi to species level for 91 fungal species from 28 families and are a potential practical PCR-RFLP tool for identifying basidiomycetes in plants from field samples.

The results outlined in this paper show that while interspecific variation of the ectomycorrhizal fungi ITS region is relatively high, intraspecific variability is very limited and that ITS restriction fragment analysis has potential for developing species-level markers for many, but not necessarily all, ectomycorrhizal fungi species. It appears that ITS-RFLP is a potent tool for the taxonomic study of ectomycorrhizal fungi, with the minute amounts of DNA required and the high reproducibility of this procedure making it an ideal method both for studying population heterogeneity in the field and the identification and monitoring of specific strains introduced into the soil in controlled mycorrhization programs.

\section{Acknowledgments}

This project was supported by grants from the Brazilian agencies FNDCT/FINEP, CNPq and FAPEMIG.

\section{References}

Allen MF (1991) The ecology of mycorrhizae. Cambridge University Press, Cambridge.

Amicucci A, Rossi I, Potenza L, Zambonelli A, Agostini D, Palma F and Stocchi V (1996) Identification of ectomycorrhizae from Tuber species by RFLP analysis of the ITS region. Biotechnol Lett 18:821-826.

Bruns TD, White TJ and Taylor JW (1991) Fungal molecular systematics. Annu Rev Ecol Syst 22:525-564.

De la Bastide, PY, Kropp BD and Piché Y (1995) Mechanisms for the development of genetically variable mycorrhizal in the ectomycorrhizal fungus Laccaria bicolor. Appl Environ Microbiol 61:3609-3616.

Egger KN (1995) Molecular analysis of ectomycorrhizal fungal communities. Can J Bot 73:1415-1422.
Erland S (1995) Abundance of Tylospora fibrilosa ectomycorhizas in a South Swedish spruce forest measured by RFLP analysis of the PCR-amplified rDNA ITS region. Mycol Res 99:1425-1428.

Erland S, Henrion B, Martin F, Glover LA and Alexander IJ (1994) Identification of the ectomycorrhizal basidiomycete Tylospora fibrillosa Donk by RFLP analysis of the PCRamplified ITS and IGS regions of ribosomal DNA. New Phytol 126:525-532.

Farmer DJ and Sylvia DM (1998) Variation in the ribosomal DNA internal transcribed spacer of a diverse collection of ectomycorrhizal fungi. Mycol Res 102:859-865.

Gardes M and Bruns TD (1996) Community structure of ectomycorrhizal fungi in a Pinus muricata forest: above- and below-ground views. Can J Bot 74:1572-1583.

Gardes M, White TJ, Fortin JA, Bruns TD and Taylor JW (1991) Identification of indigenous and introduced symbiotic fungi in ectomycorrhizae by amplification of nuclear and mitochondrial ribosomal DNA. Can J Bot 69:180-190.

Glen M, Tommerup IC, Bougher NL and O'Brien PA (2001a) Interspecific and intraspecific variation of ectomycorrhizal fungi associated with Eucalyptus ecosystems as revealed by ribosomal DNA PCR-RFLP. Mycol Res 105:843-858.

Glen M, Tommerup IC, Bougher NL and O'Brien PA (2001b) Specificity, sensitivity and discrimination of primers for PCR-RFLP of larger basidiomycetes and their applicability to identification of ectomycorrhizal fungi in Eucalyptus forests and plantations. Mycol Res 105:138-149.

Gomes EA, Barros EG, Kasuya MCM and Araújo EF (1999) Molecular characterization of Pisolithus spp. isolates by rDNA PCR-RFLP. Mycorrhiza 8:197-202.

Henrion B, Chevalier G and Martin F (1994) Typing truffle by PCR amplification of the ribosomal DNA spacers. Mycol Res 98:37-43.

Henrion B, Le Tacon F and Martin F (1992) Rapid identification of genetic variation of ectomycorrhizal fungi by amplification of ribosomal RNA genes. New Phytol 122:289-298.

Hillis DM and Dixon Mt (1991) Ribosomal DNA: molecular evolution and phylogenetic inference. The Quat Rev of Biol 66:411-453.

Junghans DT, Gomes EA, Guimarães WV, Barros EG and Araújo EF (1998) Genetic diversity of the ectomycorrizal fungus Pisolithus tinctorius based on RAPD-PCR analysis. Mycorrhiza 7:243-248.

Karén O, Hogberg N, Dahlberg A, Jonsson L and Nylund J-E (1997) Inter- and intraspecific variation in the ITS region of rDNA of ectomycorrhizal fungi in Fennoscandia as detected by endonuclease analysis. New Phytol 136:313-325.

Martin MP, Högberg N and Nylund J-E (1998) Molecular analysis confirms morphological reclassification of Rhizopogon. Mycol Res 102:855-858.

Marx DH (1969) The influence of ectotrophic mycorrhizal fungi on the resistance of pine roots to pathogenic infections. I. Antagonism of mycorrhizal fungi to root pathogenic fungi and soil bacteria. Phytopathology 59:153-163.

Molina R, Massicotte H and Trappe JM (1992) Specificity phenomena in mycorrhizal symbiosis: community-ecological consequences and practical implications. In: Allen MF (ed) Mycorrhizal Functioning - An Integrated Plant - Fungal Process. Chapman and Hall, New York. 
Nei M and Li WH (1979) Mathematical model for studying genetic variation in terms of restriction endonucleases. Proc Nat Acad Sci USA 76:5269-5273.

Paolocci F, Angelini P, Cristofari E, Granetti B and Arcioni S (1995) Identification of Tuber spp. and corresponding ectomycorrhizae through molecular markers. J Sci Food Agric 69:511-517.

Sanders IR, Justin PC and Wiemken AW (1996) The genetic diversity of arbuscular mycorrhizal fungi in natural ecosystems - a key to understanding the ecology and functioning of the mycorrhizal symbiosis. New Phytol 133:123-134
Schäfer C and Wöstemeyer J (1992) Random primer dependent PCR differentiates aggressive from non-aggressive isolates of the oilseed rape pathogen Phoma lingam (Leptosphaeria maculans). J Phytopathology 136:124-136.

Smith SE and Read DJ (1997) Mycorrhizal symbiosis. 2 ed. Academic Press, London.

White TJ, Bruns T, Lee S and Taylor J (1990) Amplification and direct sequencing of fungal ribosomal RNA genes for phylogenetics. In: Innis MA, Gelfand DH, Sninsky JJ and White TJ (eds) PCR protocols. A guide to methods and applications. Academic Press, San Diego, pp. 315-322. 